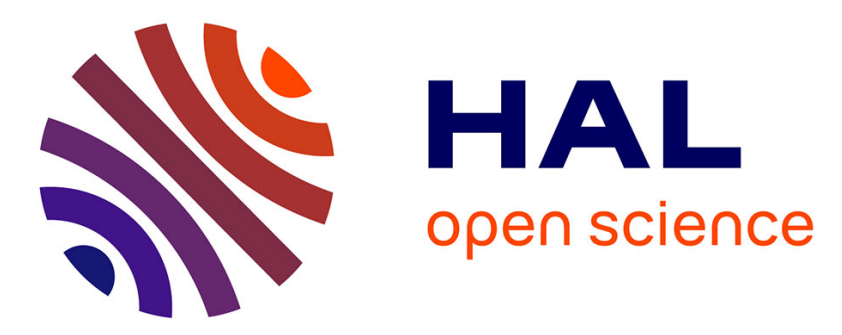

\title{
Accessory cells in the gill epithelium of the freshwater rainbow trout Salmo gairdneri
}

M. Pisam, Patrick Prunet, A. Rambourg

\section{To cite this version:}

M. Pisam, Patrick Prunet, A. Rambourg. Accessory cells in the gill epithelium of the freshwater rainbow trout Salmo gairdneri. The American journal of anatomy, 1989, 184 (4), pp.311-320. 10.1002/aja.1001840406 . hal-02727991

\section{HAL Id: hal-02727991 \\ https://hal.inrae.fr/hal-02727991}

Submitted on 2 Jun 2020

HAL is a multi-disciplinary open access archive for the deposit and dissemination of scientific research documents, whether they are published or not. The documents may come from teaching and research institutions in France or abroad, or from public or private research centers.
L'archive ouverte pluridisciplinaire HAL, est destinée au dépôt et à la diffusion de documents scientifiques de niveau recherche, publiés ou non, émanant des établissements d'enseignement et de recherche français ou étrangers, des laboratoires publics ou privés. 


\title{
Accessory Cells in the Gill Epithelium of the Freshwater Rainbow Trout Salmo gairdneri
}

\author{
M. PISAM, P. PRUNET, AND A. RAMBOURG \\ Département de Biologie, Centre d'Etudes Nucléaires de Saclay, 91191 Gif-sur-Yvette, France
}

\begin{abstract}
Two types of mitochondria-rich cells were identified in the gill epithelium of the freshwater-adapted rainbow trout, Salmo gairdneri, after selective impregnation of their tubular system with reduced osmium. A first type consisted of large cells with a poorly developed and loosely anastomosed tubular system; thus, that resembled the chloride cells commonly encountered in the gill epithelium of freshwater-adapted euryhaline fishes. A second type comprised smaller cells with an extensively developed and tightly anastomosed tubular system. These never reached the basal lamina of the gill epithelium and were adjacent to chloride cells, to which they were linked by shallow apical junctions (100-200 $\mathrm{nm}$ ); thus, they resembled accessory cells, which are currently found in the gill epithelium of seawater-adapted fishes but are usually lacking in freshwater living fishes. Transfer of the freshwater-adapted trout into seawater induced the proliferation of the tubular system in the chloride cells and the formation of lateral plasma membrane interdigitations between accessory cells and the apical portion of the chloride cells. The length of the apical junction sealing off this extended intercellular space was reduced to 20-50 $\mathrm{nm}$. The tubular system of the accessory cells was not modified. The extension of the tubular system in the chloride cells of the seawater-adapted fishes indicated that, as in most euryhaline fishes, these cells have a role in the adaptation of the rainbow trout to seawater. In contrast, the function of the presumptive accessory cells in freshwater trout remains to be established.
\end{abstract}

\section{INTRODUCTION}

Among euryhaline fishes living in fresh water, some species (e.g., the salmon, Salmo salar) easily pass into seawater during a determined period of their biological cycle owing to preadaptation to seawater life called smoltification. When the ultrastructural features of the gill epithelium in this species were examined during smoltification, it was noted that structures normally found in seawater-adapted euryhaline fishes were already present in smolts kept in a freshwater environment. Chloride cells were large and displayed an extensive tubular system in continuity with their basolateral plasma membranes; they were attached to accessory cells by shallow apical junctions (Pisam et al., 1988). Another salmonid, the rainbow trout (Salmo gairdneri) does not undergo smoltification. It may nevertheless adapt itself to seawater, although with much difficulty, after a transient desequilibrium of its hydromineral balance. The gill epithelium of this freshwater fish was examined by electron microscopy after selective impregnation of the tubular system in chloride cells. Unexpectedly, despite the limited adaptability of this fish to seawater life, chloride cells were found to be associated with smaller and denser mitochondriarich cells, which presumably are accessory cells. It is the purpose of this paper to describe the ultrastructural features of both cell types in freshwater and seawater rainbow trout and to discuss the significance of accessory cells in a freshwater environment.

\section{MATERIALS AND METHODS}

Juvenile rainbow trout (Salmo gairdneri) of $3.5 \mathrm{gm}$ average weight were kept in laboratory holding tanks filled with fresh water containing $0.86 \mathrm{mM} /$ liter $\mathrm{Na}^{+}$ and $0.52 \mathrm{mM} /$ liter $\mathrm{Ca}^{++}$. Some fishes gradually adapted to artificial seawater in the following way: they were maintained for 7 days in $20 \%$ artificial seawater; then salinity was increased to $26 \%$ for 3 days to reach finally a level of $30 \%$ seawater, in which the fishes were kept for 1 week.

Gills from freshwater and seawater-adapted trout were quickly dissected and fixed for $1 \mathrm{hr}$ at room temperature in $2 \%$ glutaraldehyde buffered with $0.08 \mathrm{M}$ sodium cacodylate, $\mathrm{pH}$ 7.5. The gill fragments were then postfixed for $1 \mathrm{hr}$ in 1:1 potassium ferrocyanide (3\%)osmium tetroxide (2\%) (Karnovsky, 1971), dehydrated, and embedded in Epon. Sections were stained for $2 \mathrm{~min}$ with lead citrate and examined at $80 \mathrm{kV}$ with a Philips EM 400 electron microscope.

For stereoscopy, sections were placed on the goniometric stage of the electron microscope; stereopairs were obtained by taking pictures of the same field after tilting the specimen at $-18^{\circ}$ and $+18^{\circ}$ from the original $\left(0^{\circ}\right)$ position of the stage. A three-dimensional image of the structures was obtained by looking at properly adjusted pairs of such photographs with a stereoscopic binocular lens.

The relative number of small and large mitochondria-rich cells in the gill epithelium of freshwater- and

Received July 8, 1988. Accepted December 10, 1988.

Address reprint requests to Dr. M. Pisam, Département de Biologie, CEN, Saclay, 91191 Gif-Sur-Yvette Cedex, France. 


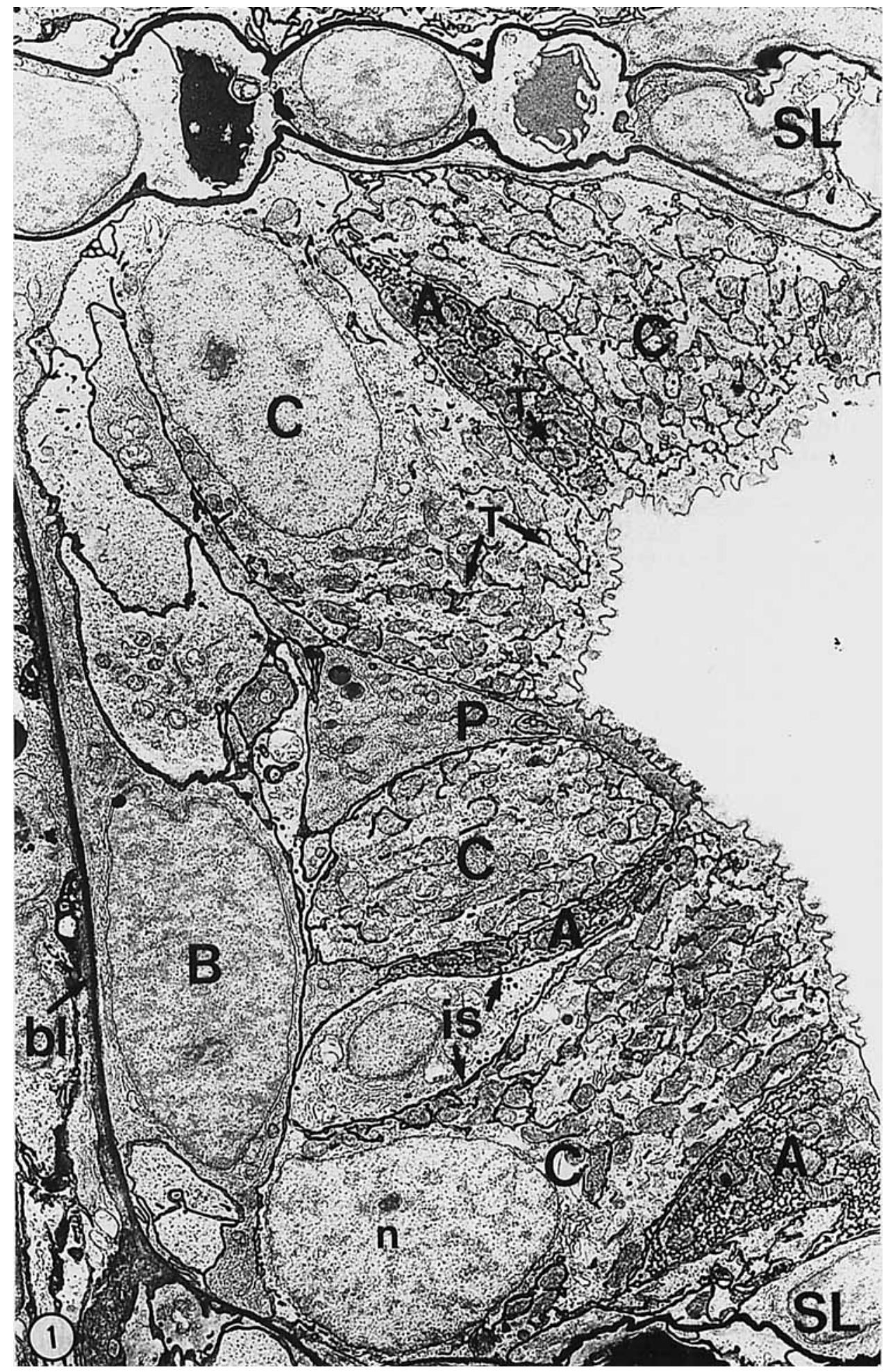

Fig. 1. Interlamellar region in freshwater trout gill epithelium. The primary gill epithelium located between two secondary lamellae shows two types of mitochondria-rich cells: The large mitochondriarich cells, or chloride cells, and the small mitochondria-rich cells, or accessory cells. These cell types differ in the configuration of their tubular system. This tubular system, which is an intracellular expansion of the intercellular space, is densely stained by reduced osmium. It is sparse and loosely anastomosed in chloride cells, whereas it is abundant and tightly anastomosed in the accessory cells. The mitochondria-rich cells are separated from the basal lamina of the primary epithelium by basal cells. $\times 4,200$. 
seawater-adapted trout was determined by counting, in three fishes for each physiological condition, the number of cells per interlamellar region. Cells were counted, at the base of the filaments, in sections running parallel to the long axis of the primary lamella and perpendicular to the secondary lamallae. Surface areas of both types of cells were determined on thin sections passing through the nucleus; they were calculated, from 10 cells of each type in each physiological condition, using a Kontron M15 image analyzer on micrographs enlarged to a final magnification of $\times 2,800$. Dif- ferences in numbers and surface areas of "mitochondria-rich cells" between freshwater- and seawater-adapted trout were assessed using Student's $t$ test.

\section{RESULTS}

The gill of the trout consists of four or five branchial arches. As can be seen in scanning electron micrographs (Olson and Fromm, 1973; Kendall and Dale, 1979; Jacobs et al., 1981), each branchial arch bears several primary lamellae (or filaments), which in turn give rise to secondary lamellae. Numerous secondary lamallae radiate at right angles from a primary lamella. They are shortest near the tip of the primary lamella and increase in length to the midpoint from which their length remains constant to its base (Kendall and Dale, 1979). Both types of lamellae are covered by an epithelial sheet which, as proposed by Laurent and Dunel (1978), is usually subdivided in two regions: A primary epithelium covering the filaments and a secondary epithelium covering the secondary lamellae. In a section running parallel to the long axis of the primary lamella (Fig. 1), the primary epithelium fills the interlamellar space separating the bases of two consecutive secondary lamellae. This is a pluristratified epithelium (Morgan and Tovell, 1973) consisting of basal cells resting on the basal lamina and two main types of superficial cells in contact with the outside medium: the so-called "pavement cells," which are flattened or piriform and the ovoid "mitochondria-rich cells" (Fig. 1 ). In the gill epithelium of most euryhaline fishes, the latter cells display in their cytoplasm a network of membranous tubules continuous with their basolateral plasma membrane (Philpott, 1966; Kikuchi, 1977; Karnaky, 1980; Pisam, 1981). This system of tubules has been referred to as a tubular system to distinguish it from two other intracytoplasmic membranous systems usually encountered in the gill mitochondria-rich cells: The endoplasmic reticulum and the vesiculotubular system (Pisam, 1981).

Owing to the intense osmiophilia of this "tubular system" after reduced osmium staining, two types of mitochondria-rich cells were clearly distinguished in the primary epithelium of both freshwater- and seawater-adapted trout: 1) Large and pale cells that resemble the "chloride cells" of the gill epithelium of most euryhaline fishes; and 2) smaller and denser cells, which were thought to be accessory cells, as they were regularly located adjacent to the apical portion of the chloride cells (Fig. 1). The surface area of both cell types did not change significantly with the salinity of the surrounding medium (Table 1 ). Their ultrastructural features, however, were modified as described below.
TABLE 1. Mean surface areas (in $\mu \mathrm{m}^{2} \pm$ S.D.) of mitochondria-rich cells in sections of the primary gill epithelium from freshwater- or seawater-adapted trout

\begin{tabular}{lccc}
\hline & $\begin{array}{c}\text { Number } \\
\text { of cells }\end{array}$ & $\begin{array}{c}\text { Chloride } \\
\text { cells }^{*}\end{array}$ & $\begin{array}{c}\text { Accessory } \\
\text { cells }^{*}\end{array}$ \\
\hline $\begin{array}{l}\text { Freshwater } \\
\text { Seawater }\end{array}$ & 10 & $124 \pm 24$ & $68 \pm 18$ \\
\hline
\end{tabular}

*Difference between freshwater and seawater not significantly different $(P>0.05)$.

\section{Mitochondria-Rich Cells in Freshwater Trout}

In fresh water, chloride cells were relatively voluminous (Table 1) and ovoid or cylindrical in shape (Figs. $1,2)$. Their wide apical pole, which was flattened or slightly convex, displayed short and regularly aligned microvilli protruding into the surrounding medium (Fig. 1). Their basal region containing the nucleus was usually in contact with the basal lamina underlying the epithelium. The membranous system, in continuity with the basolateral surface, was poorly developed; in contrast to the general rule in gill chloride cells, it was not exclusively tubular and displayed portions of unfenestrated cisternae (Fig. 7). Owing to their strong osmiophilia, these cisternae were easily distinguished from the cisternae of the endoplasmic reticulum, which were not osmiophilic (Fig. 3); they were continuous with loosely and irregularly anastomosed membranous tubules to form an osmiophilic network located mainly in the supranuclear region (Fig. 2). Tubular extensions of this membranous system were preferentially encountered in the apical portion of the cell, where they were intermingled with numerous independent spheroid or ovoid membrane-bound bodies (Figs. 2). The chloride cells were attached to pavement cells by deep apical junctions from 450 to $650 \mathrm{~nm}$ in length (Fig. 11).

The presumptive accessory cells (Figs. 4,5 ) were significantly smaller, narrower, and less numerous (Tables $1,2)$ than the chloride cells. They were invariably adjacent to the apical portion of the latter and never reached the basal lamina of the epithelium (Fig. 1). Their narrow apex, which was in contact with the external medium, contained sparse vesicular and tubular structures (Fig. 6). They were endowed with an extensive tubular system uniformly distributed throughout the cell (Figs. 1,5). At higher magnification (Fig. 4) and in stereopairs (Figs. 6, 8), this tubular system consisted

$\begin{array}{ll}\text { A } & \text { small mitochondria-rich cell or accessory cell } \\ \text { am } & \text { apical membrane } \\ \text { B } & \text { basal cells } \\ \text { bl } & \text { basal lamina } \\ \text { C } & \text { large mitochondria-rich cell or chloride cell } \\ \text { ER } & \text { endoplasmic reticulum } \\ \text { G } & \text { Golgi apparatus } \\ \text { IS } & \text { intercellular space } \\ \text { lbm } & \text { laterobasal plasma membrane } \\ \text { m } & \text { mitochondria } \\ \text { MB } & \text { membrane-bound body } \\ \text { n } & \text { nucleus } \\ \text { P } & \text { pavement cell } \\ \text { SL } & \text { seondary lamella } \\ \text { T } & \text { tubular system }\end{array}$



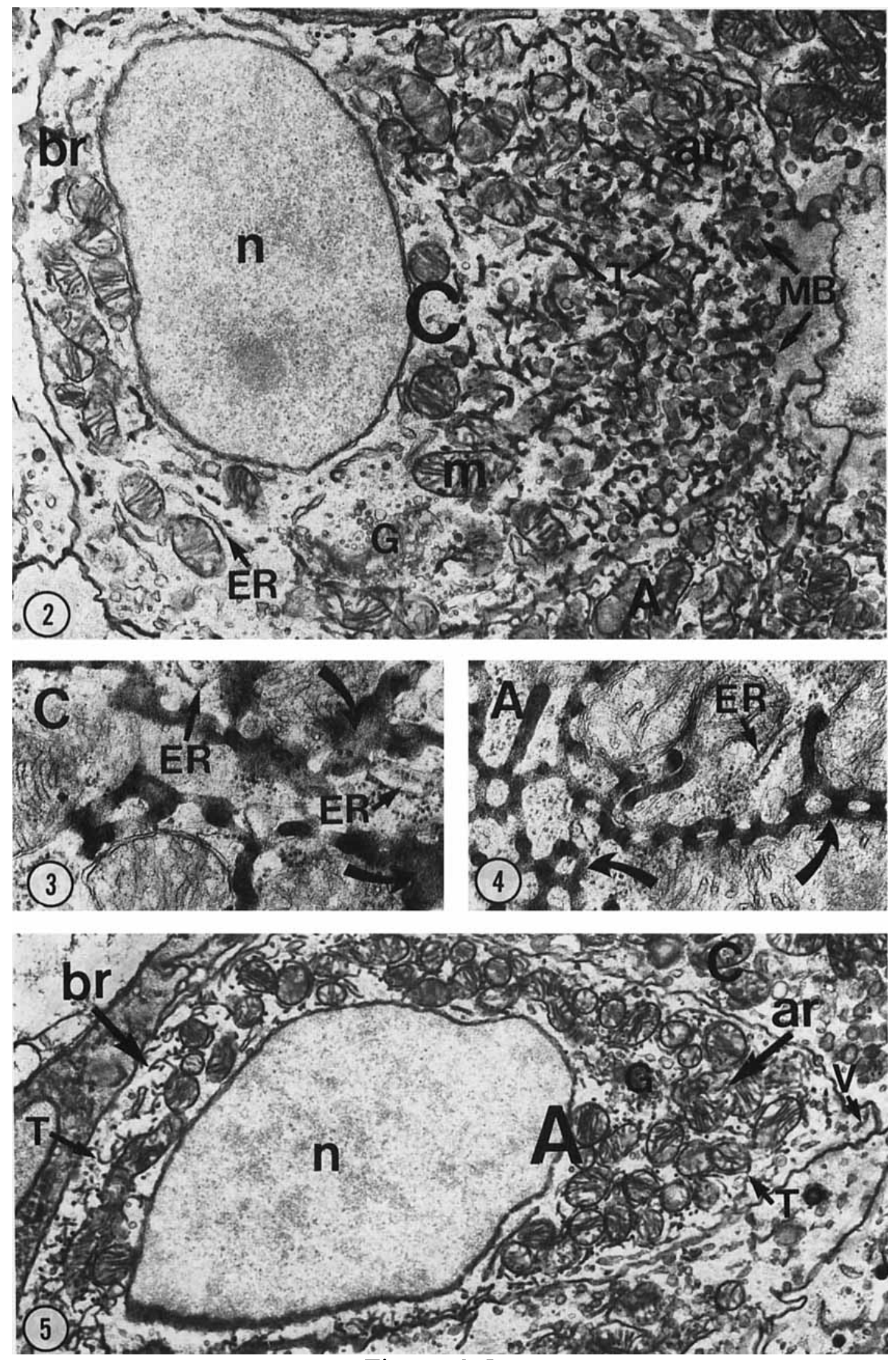

Figures 2-5. 
TABLE 2. Mitochondria-rich cell numbers (mean \pm S.D.) in interlamellar region of primary gill epithelium from freshwater- and seawater-adapted trout

\begin{tabular}{lcccc} 
& Number $^{1}$ & Chloride cells* & Accessory cells** & $\begin{array}{c}\text { chloride cells and } \\
\text { accessory cells }\end{array}$ \\
\hline Freshwater & 50 & $2.65 \pm 0.90$ & $0.94 \pm 0.50$ & 0 \\
Seawater & 50 & $2.06 \pm 0.90$ & $0.92 \pm 0.46$ & $1.05 \pm 1.6$ \\
\hline
\end{tabular}

${ }^{1}$ Number of interlamellar regions.

*Difference between freshwater and seawater significantly different $(P<0.001)$.

**Difference not significant $(P>0.05)$.

exclusively of tightly anastomosed membranous tubules forming a continuous meshwork with numerous small regular meshes. The diameter of the tubules, how ever, was smaller $(25-30 \mathrm{~nm})$ in the accessory cells than in the chloride cells (50-80 nm) (Figs. 6, 9, 13). The accessory cells were bound to pavement cells by deep $(450-650 \mathrm{~nm}$ in length) apical junctions and to adjacent chloride cells by shallower $(100-200 \mathrm{~nm})$ junctions (Fig. 12).

\section{Mitochondria-Rich Cells in Seawater-Adapted Trout}

When trout were progressively adapted to seawater, the size of both types of mitochondria-rich cells remained unaltered (Table 1); the number of accessory cells was not modified, whereas the number of chloride cells was slightly diminished (Table 2 ). In the accessory cells, the ultrastructural characteristics of the three main intracytoplasmic membranous systems remained unaltered. In the chloride cells, in contrast, the tubular system, which was poorly developed in freshwater (Fig. 9 ), became conspicuous in seawater; it consisted of tightly anastomosed membranous tubules uniformly distributed throughout the cell (Fig, 10). In both types of cells, transfer into seawater did not modify the diameter of the membranous tubules making up the tubular system.

In seawater-adapted fishes, the accessory cells sent numerous interdigitating processes into the apical portions of the adjacent chloride cells (Fig. 14; Table 2). As a result, the intercellular space separating the two cell types, relatively straight in freshwater, became sinuous in seawater (Figs. 13, 14). Furthermore, the apical junctions closing these expanded intercellular spaces were significantly shallower ( 25 to $50 \mathrm{~nm}$ in length) in seawater (Fig. 14) than in fresh water (Fig. 12).

\section{DISCUSSION}

Several electron microscope studies have demonstrated the existence of at least two types of chloride cells in the gill epithelium of some freshwater-adapted euryhaline teleosts (Doyle and Gorecki, 1961; Straus, 1963; Bierther, 1970; Pisam et al., 1987). In the gill epithelium of the freshwater rainbow trout, in contrast, only one type of chloride cell has been observed in conventionally stained thin sections or in specimens prepared for scanning electron microscopy (Olson and Fromm, 1973; Kendall and Dale, 1979; Laurent and Dunel, 1980). This was confirmed in the present study, as only the large, pale mitochondria-rich cells resembled the chloride cells of fresh-water-adapted fishes.

Upon closer examination after reduced osmium staining, the basolateral membrane invaginations of these chloride cells were found to consist partly of unfenestrated cisternae and partly of loosely anastomosed membranous tubules. As a result, the tubular system is poorly developed (Fig. 15) as is the case in gill chloride cells of most freshwater-adapted euryhaline fishes (Doyle and Gorecki, 1961; Pisam, 1981). In most chloride cells, the membranous system derived from infoldings of the basolateral plasma membrane is thought to contain molecules of $\mathrm{Na}^{+}-\mathrm{K}^{+}$-adenosine triphosphatase (ATPase) (Karnaky et al., 1976; Hootman and Philpott, 1979; Philpott, 1980). The scarcity of membranous tubules in chloride cells would thus be the ultrastructural counterpart of the low $\mathrm{Na}^{+}-\mathrm{K}^{+}$-ATPase values detected in the gills of the freshwater rainbow trout and might explain the poor adaptability of this species to seawater (Boeuf and Harache, 1984). When, however, the freshwater trout is progressively adapted to artificial seawater, the unfenestrated cisternae are no longer visible in the basolateral membrane invaginations of the gill chloride cells; they are replaced by a system of tightly anastomosed membranous tubules (Fig. 15) similar to the tight tubular network depicted in chloride cells of seawater-adapted euryhaline fishes. Thus, in this respect, chloride cells of the rainbow trout do not differ from those of other euryhaline fishes and might have a
Figs. 2, 3. Chloride cells in freshwater trout gill epithelium.

Fig. 2. This ovoid cell has a tubular system that is more abundant in the apical region (ar) than in the basal region (br). The apex of the cell is filled with large membrane-bound bodies intermingled with elements of the tubular system. $\times 14,000$

Fig. 3. In the supranuclear region, the membranous system originating from the laterobasal cell surface shows cisternae (curved arrows) that are densely impregnated with reduced osmium. These cisternae are readily distinguished from the ER cisternae, which remain

\section{unstained and are lined with ribosomes. $\times 34,000$.}

Figs. 4, 5. Accessory cells in freshwater trout gill epithelium.

Fig. 4. In the supranuclear region, the membranous system originating from the laterobasal surface consists exclusively of anastomosed membranous tubules (curved arrows). $\times 34,000$.

Fig. 5. The cell is pear-shaped, with a tubular system uniformly distributed throughout the apical (ar) and basal (br) regions. Vesicular structures (V) are scarce in the narrow apex. $\times 12,000$. 

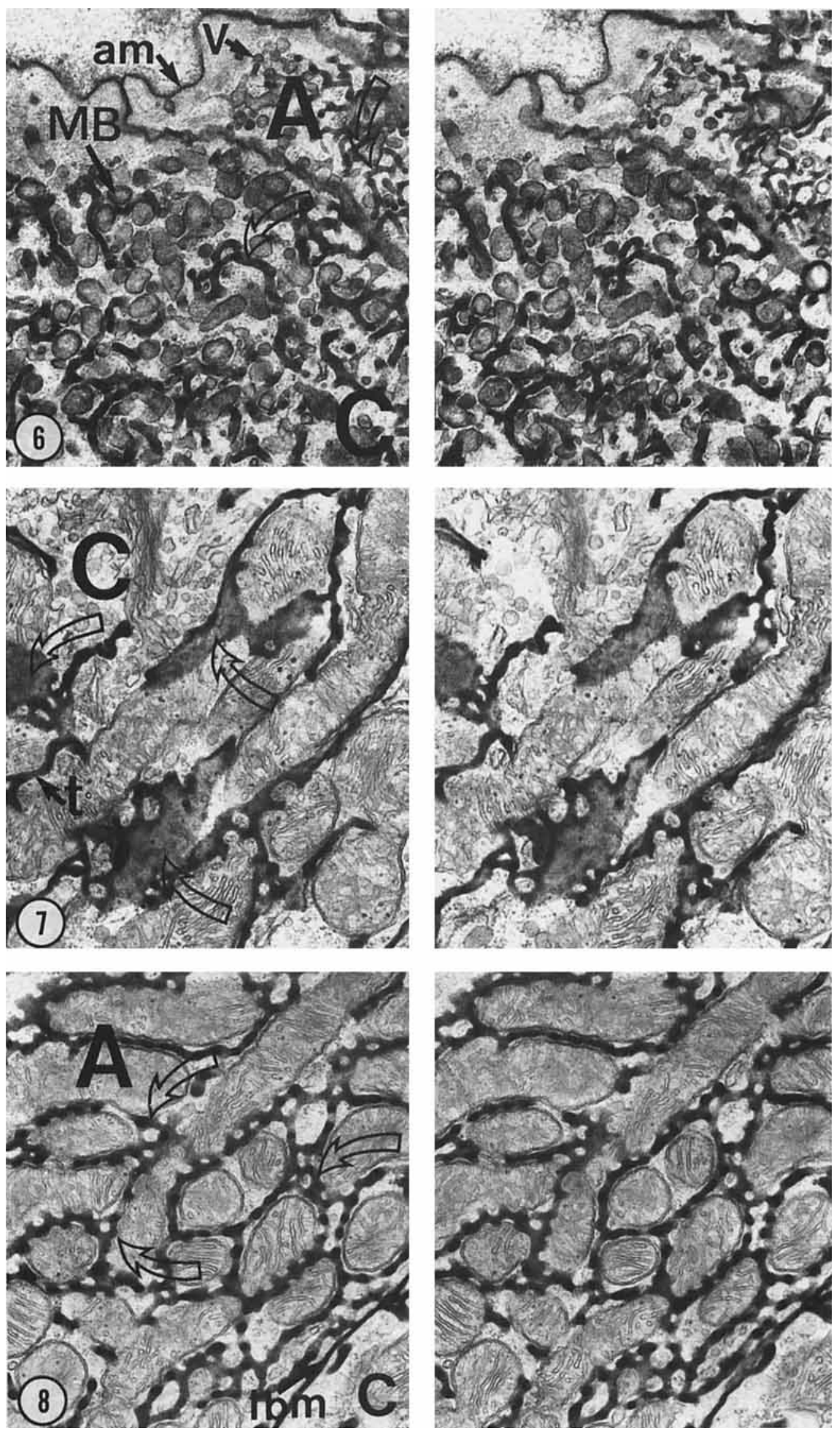

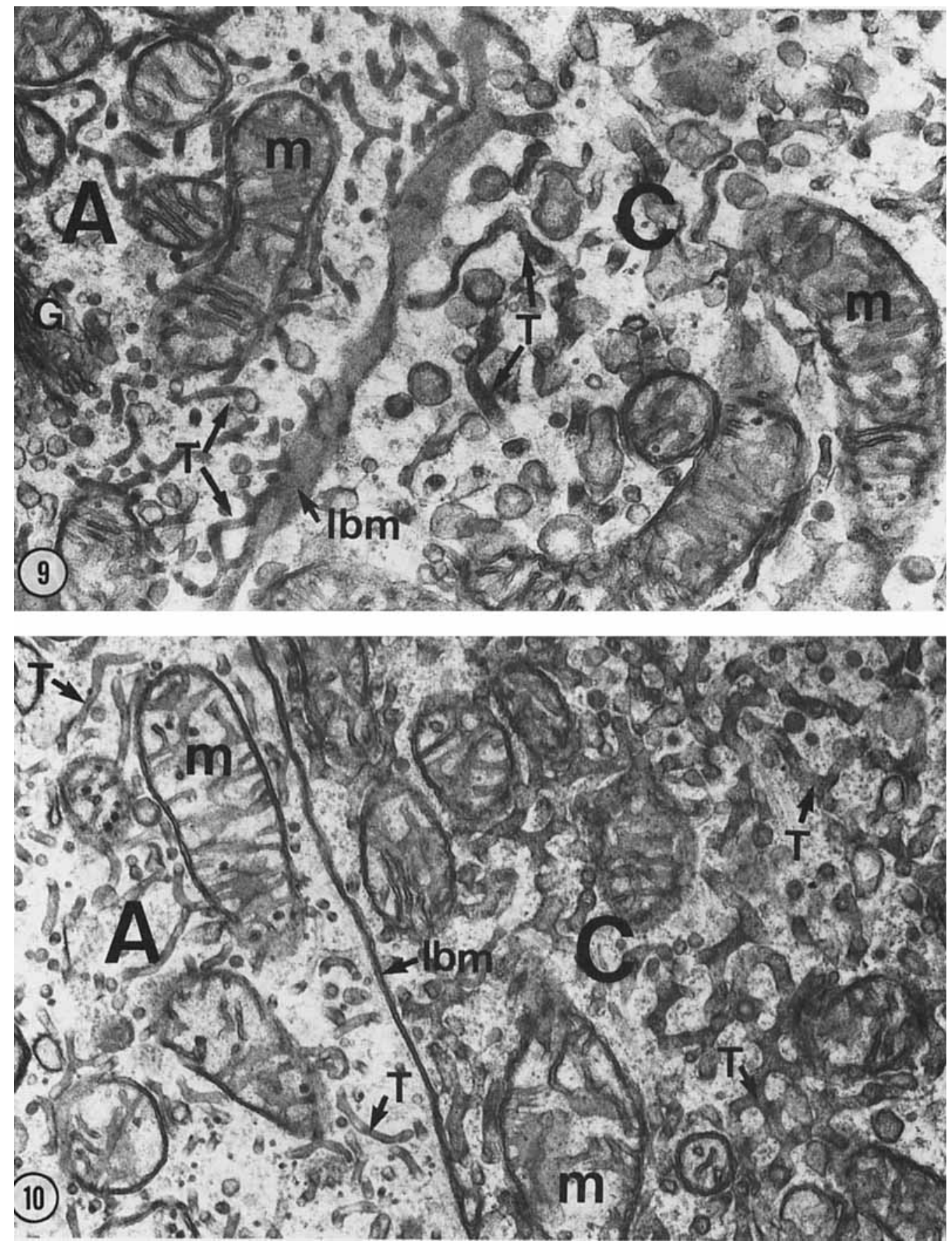

Figs. 9, 10. Portions of accessory and chloride cells in gill epithelium. $\times 36,000$.

Fig. 9. Freshwater trout. The accessory cell at left shows a tubular system made up of tightly anastomosed tubules. At right, in the chloride cell, the tubular system consists of sheets and tubules loosely anastomosed.

Figs. 6-8. Freshwater trout. Stereopairs of the stained membranous system derived from the laterobasal plasma membrane in mitochondria-rich cells. $\times 22,000$

Fig. 6. Apex of both types of mitochondria-rich cells. In the chloride cell (at left), the membranous system (curved arrows) consists of tubules larger and more loosely anastomosed than those of the accessory cell (at right). Numerous voluminous, apical, membrane-bound bodies are observed exclusively in the chloride cells. Note rare, small vesicular structures (V) in the apex of the accessory cell.
Fig. 10. Seawater-adapted trout. The tubular system of the accessory cell resembles that of the freshwater fish: the density and the diameter of the tubules are not modified. In contrast, in the chloride cell, the tubular system appears as a dense network of anastomosed tubules around numerous, small, and polygonal meshes; as in the freshwater trout, the diameter of these tubules is larger than that of the membranous tubules observed in the accessory cell.

Fig. 7. In the supranuclear region of the chloride cell, the membranous system consists of unfenestrated cisternae (curved arrows) interconnected by rare tubular elements $(\mathrm{t})$.

Fig. 8 . In the supranuclear region of the accessory cell, the membranous tubules are anastomosed to form an extensive network displaying numerous, small, regular, and polygonal meshes (arrows). 

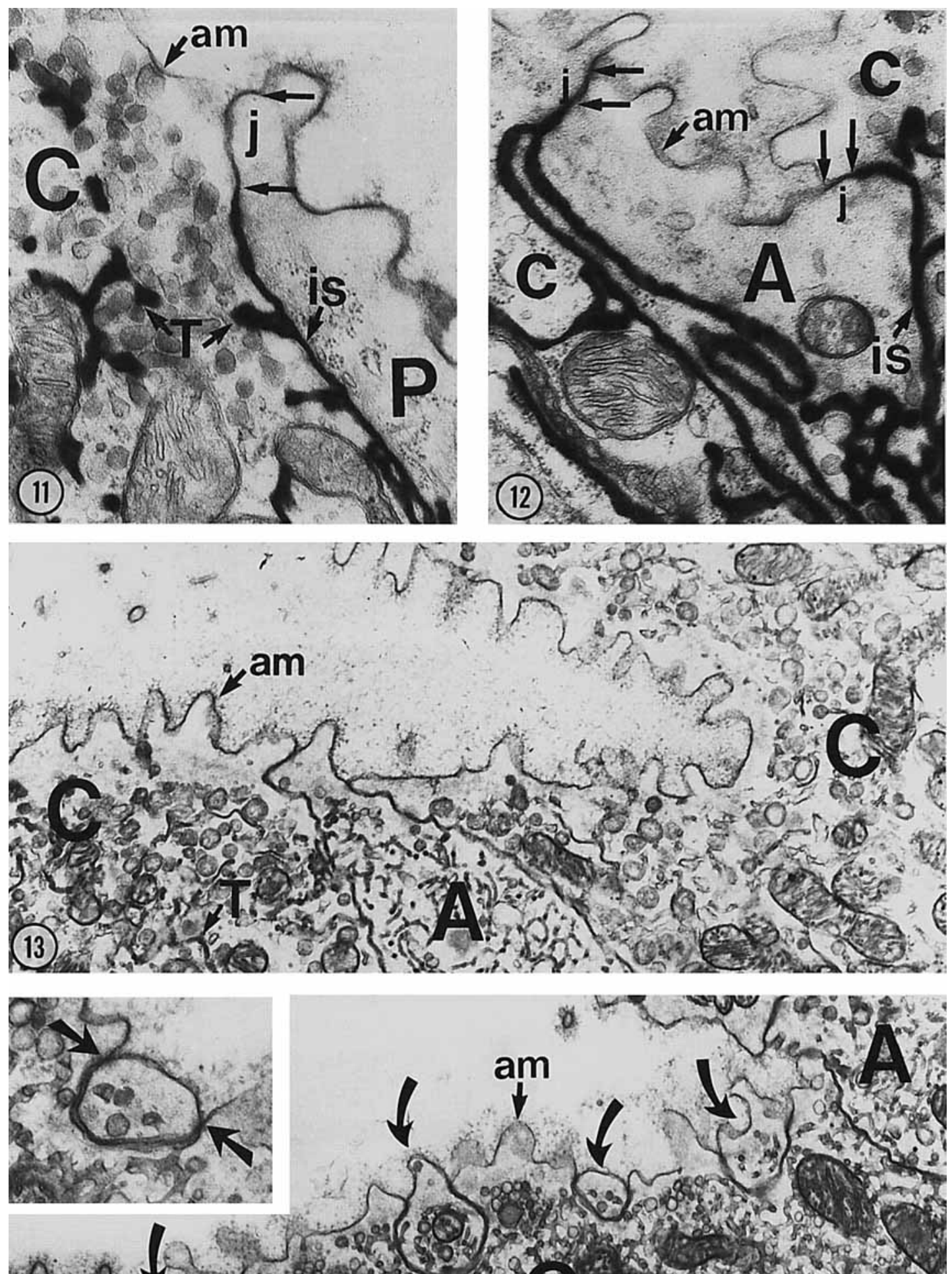

$$
\text { . }
$$



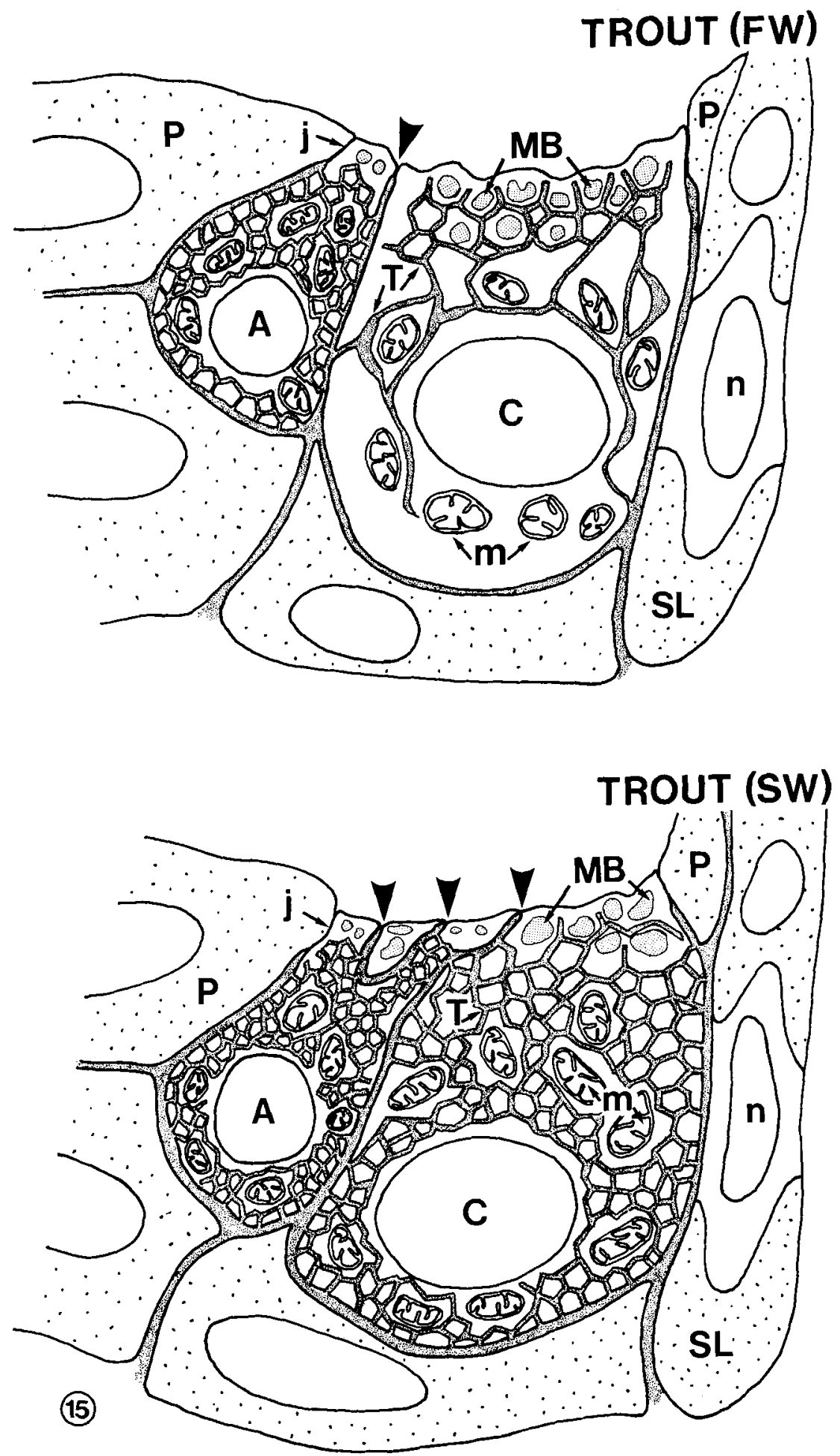

Fig. 15. Schematic representation of the ultrastructural differences between "mitochondria-rich cells" from freshwater and seawater trouts.

In freshwater (FW) chloride cells, the membranous system connected with the basolateral plasma membrane is poorly developed. In the apical region, anastomosed tubules are intermingled with large membrane-bound bodies; in the perinuclear region, the membranous system consists mainly of anastomosed cisternae. In contrast, the accessory cell displays an abundant tubular system in which tubules are anastomosed to form a dense network showing small, regular, and polygonal meshes. The apical junction binding accessory and chloride cells (arrowhead) is shorter than the junction ( $j$ ) located between the pavement cell and the accessory or chloride cells.

In seawater (SW), the size and shape of both cell types are not significantly modified. As compared with freshwater fish, the main ultrastructural alterations are: 1) Development of the tubular system in the chloride cell, which consists of a dense network of anastomosed tubules with numerous, small, polygonal meshes; and 2) formation of numerous apical interdigitations between the accessory cell and the apex of the adjacent chloride cell, sealed off by shallow junctions (arrowheads). 
role in the adaptation of this sedentary freshwater fish (Boeuf and Harache, 1984) to seawater life.

Impregnation with reduced osmium of the gill epithelium of the freshwater trout also demonstrates the presence of smaller, denser mitochondria-rich cells displaying a well-developed tubular system. These small cells are characterized by the following ultrastructural features (Fig. 15): they never reach the basal lamina of the gill epithelium; they are always adjacent to the apical portion of the chloride cells and are bound to them by junctions significantly shallower than those binding the apex of chloride cells to adjacent pavement cells. Furthermore, transfer of the trout into seawater induces the formation of numerous cytoplasmic interdigitations between these small cells and the apical portion of the chloride cells. All these ultrastructural features have been reported as specific for so-called accessory cells (Laurent and Dunel, 1980; Laurent, 1984) and thus support the conclusion that the small mitochondria-rich cells might correspond to accessory cells. Accessory cells are usually encountered in the gill epithelium of seawater-adapted fishes (Laurent and Dunel, 1980); however, presumptive accessory cells in which the tubular system remained rudimentary have been found occasionally in the gill epithelium of some freshwater-adapted euryhaline fishes (Chretien and Pisam, 1986); and recently Hwang (1988) reported the presence, in the gill of some freshwater teleosts, of multicellular complexes in which some chloride cells resemble accessory cells.

Accessory cells are usually thought to have a role in the osmoregulation of seawater-adapted fishes (Sardet et al., 1979). When present in the gill epithelium of a freshwater fish such as the freshwater smolt of Salmo salar, accessory cells are presumed to participate in a preadaptation of the fish to seawater (Pisam et al., 1988). The observations of accessory cells with a highly developed tubular system is thus rather surprising in a fresh-water sedentary fish which ". . . in spite of a certain degree of euryhalinity ... suffers significant losses in seawater ..." (Boeuf and Harache, 1984). In contrast to what occurs in chloride cells, the tubular system of these accessory cells remains unaltered when the trout is adapted to seawater (Fig. 15).

Furthermore, $\mathrm{Na}^{+}-\mathrm{K}^{+}$-ATPase, which is an integral part of the tubular system in chloride cells, has so far not been detected in accessory cells (Hootman and Philpott, 1980), so that their role in the transfer of both ions might be questioned. In the freshwater trout as in freshwater smolt, accessory cells are always associated with chloride cells. Transfer to seawater induces in both species the formation of interdigitations between the two cells and a modification of the apical junction sealing off the extended intercellular space. The chloride cells and their associated accessory cells should thus be considered as a functional unit, as suggested by Sardet et al. (1979). The role of the accessory cell in this functional unit, however, remains to be established.

\section{ACKNOWLEDGMENTS}

The authors express gratitude to Professor H. Bern for his critical reading of the manuscript. The drawing (Fig. 15) was prepared by Michèle Lucarain.

\section{LITERATURE CITED}

Bierther, M. 1970 Die chloridzellen des Stichlings. Z. Zellforsch., 107:421-446.

Boeuf, G., and Y. Harache 1984 Adaptation osmotique à l'eau de mer de différentes espèces (Salmo trutta, Salmo gairdneri, Salvelinus fontinalis) et hybride (Salmo trutta, Salvelinus fontinalis) de Salmonidés. Aquaculture, 40:343-358.

Chrétien, M., and M. Pisam 1986 Cell renewal and differentiation in the gill epithelium of fresh- or salt-water-adapted euryhaline fish as revealed by ${ }^{3} \mathrm{H}$-thymidine radioautography. Biol. Cell, 56:137150.

Doyle, W.L., and D. Gorecki 1961 The so-called chloride cell of the fish gill. Physiol. Zool., 34:81-85.

Hootman, S.R., and C.W. Philpott 1979 Ultrachemical localization of $\mathrm{Na}+, \mathrm{K}+$ activated ATPase in chloride cells from the gills of a euryhaline telost. Anat. Rec., 193:99-130.

Hootman, S.R., and C.W. Philpott 1980 Accessory cells in teleost branchial epithelium. Am. J. Physiol., 238:R199-R206.

Hwang, P.P. 1988 Multicellular complex of chloride cells in the gills of freshwater teleosts. J. Morphol, 196:15-22

Jacobs, D., E.F. Esmond, E.L. Melisky, and C.H. Hocutt 1981 Morphological changes in gill epithelia of heat-stressed rainbow trout, Salmo gairdneri: Evidence in support of a temperatureinduced surface area change hypothesis. Can. J. Fish. Aquat. Sci., 38:16-22

Karnaky, K.J., Jr. 1980 Ion secreting epithelia: chloride cells in the head region of Fundulus heteroclitus. Am. J. Physiol., 238:R185R198.

Karnaky, K.J. Jr., L.B. Kinter, W.B. Kinter, and C.E. Stirling 1976 Teleost chloride cell. II. Autoradiographic localization of gill $\mathrm{Na}$, K-ATPase in killifish, Fundulus heteroclitus, adapted to low and high salinity environments. J. Cell Biol., 70:157-177.

Karnovsky, M.J. 1971 Use of ferrocyanide reduced osmium tetroxide in electron miscroscopy. Proc. Am. Soc. Cell Biol., 284:146 (abstract).

Kendall, M., and J. Dale 1979 Scanning and transmission electron microscopic observations of rainbow trout (Salmo gairdneri) gill. J. Fish. Res. Board Can, 36:1072-1079.

Kikuchi, S. 1977 Mitochondria rich (chloride cells) in the gill epithelia from four species of stenohaline freshwater teleosts. Cell Tiss. Res., 180:87-98.

Laurent, P. 1984 Gill interrenal morphology, In: Fish Physiology. W.S. Hoar and D.J. Randall, eds. Academic Press, New York, pp. $73-183$.

Laurent, P., and S. Dunel 1978 Relations anatomiques des ionocytes (cellules à chlorure) avec le compartiment veineux branchial: définition de deux types d'épithélium de la branchie des poissons. C.R. Acad. Sci. Paris, 286:1447-1450.

Laurent, P., and S. Dunel 1980 Morphology of gill epithelia in fish. Am. J. Physiol., 238:R147-R159.

Morgan, $M$, and $P$. Tovell 1973 The structure of the gill of the trout, Salmo gairdneri (Richardson). Z. Zellforsch., 142:147-162.

Olson, K., and P. Fromm 1973 A scanning electron microscopy study of secondary lamellae and chloride cells of rainbow trout (Salmo gairdneri). Z. Zellforsch., 143:439-449.

Philpott, C.W. 1966 The use of horseradish peroxidase to demonstrate functional continuity between the plasmalemma and the unique tubular system of the chloride cell. J. Cell Biol, 31:86A (abstract).

Philpott, C.W. 1980 Tubular system membranes of teleost chloride cells: osmotic response and transport sites. Am. J. Physiol., 238: R171-R184.

Pisam, M. 1981 Membranous systems in the "chloride cell" of teleostean fish gill, their modifications in response to the salinity of the environment. Anat. Rec., 200:401-414.

Pisam, M., A. Caroff, and A. Rambourg 1987 Two types of chloride cells in the gill epithelium of a freshwater adapted euryhaline fish: Lebistes reticulatus. Their modifications during adaptation to salt water. Am. J. Anat., 179:40--50.

Pisam, M., P. Prunet, G. Boeuf, and A. Rambourg 1988 Ultrastructural features of chloride cells in the gill epithelium of the Atlantic salmon, Salmo salar, and their modifications during smoltification. Am. J. Anat., 183:235-244.

Sardet, C., M. Pisam, and J. Maetz 1979 The surface epithelium of teleostean fish gills: cellular and functional adaptations of the chloride cell in relation to salt adaptation. J. Cell Biol., 80:96117.

Straus, L.P. 1963 A study of the fine structure of the so-called chloride cell in the gill of the guppy Lebistes reticulatus P. Physiol. Zool., 36:183-198. 